\title{
Kelola
}

Jurnal Manajemen Pendidikan

Magister Manajemen Pendidikan

e-ISSN 2549-9661

FKIP Universitas Kristen Satya Wacana

Volume: 4, No. 2, Juli-Desember 2017

jurnalkelola@gmail.com

Halaman: 205-212

\section{Analisa Faktor-Faktor yang Mempengaruhi Proses Belajar Guru-Guru Sekolah} Dasar

\author{
Indri Anugraheni \\ PGSD, Universitas Kristen Satya Wacana Salatiga \\ Indri.anugraheni@staff.uksw.edu
}

\begin{abstract}
The purpose of this research is to know and describe factors influencing elementary school teachers in Biak Numfor District, and efforts made by elementary school teachers of Biak and suggestions for the development of education especially in Biak Numfor District. The method used in this research is descriptive. The research subjects were elementary school teachers in Biak Numfor District. Data obtained by distributing instrument in the form of Questionnaire. The results of a questionnaire that was distributed to 31 elementary school teachers in Biak Numfor district showed that many of the obstacles experienced by teachers. Obstacles experienced by elementary school teachers in Biak Numfor district are teachers experiencing obstacles in preparing the lesson, teachers experience barriers in determining methods and media used in learning, teachers experience barriers in determining the evaluation used in learning. Efforts by teachers to overcome these obstacles are many students who do not have a handbook then the teachers, and teachers use the media in school. Teachers hope the attention of local governments need to be improved again.
\end{abstract}

Keywords: factors that influence, learning, efforts undertaken

\section{Article Info}




\section{PENDAHULUAN}

Pendidikan mempunyai peran dalam perkembangan suatu bangasa. Pendidikan mampu menghasilkan sumber daya manusia yang berkualitas. Guru mempunyai peranan penting dalam menciptakan sumberdaya manusia yang berkualitas. Undang-undang No 14 Tahun 2005 pasal 1 menyatakan bahwa Guru adalah pendidik profesional dengan tugas utama mendidik, mengajar, membimbing, mengarahkan, melatih, menilai, dan mengevaluasi peserta didik pada pendidikan anak usia dini jalur pendidikan formal, pendidikan dasar, dan pendidikan menengah.Guru mampu mendidik dan menumbuhkan kedewasaan siswa. Guru mampu mengajar dengan mengatur dan menciptakan kondisi lingkungan sehingga siswa dapat melakukan kegiatan pembelajaran. Membimbing adalah usaha yang dilakukan guru untuk mengantarkan siswa kearah kedewasaan baik secara jasmani atu rohani. Selain membimbing, guru juga diharapkan mampu mengarahkan, melatih serta mengevaluasi siswa (peserta didik).

Guru dalam proses pemelajaran di kelas dipandang dapat memainkan peranan penting terutama dalam membantu peserta didik untuk membangun sikap positif, membangkitkan rasa ingin tahu, mendorong kemandirian dan ketepatan logika intelektual, serta menciptakan kondisi-kondisi untuk sukses dalam belajar (Muh. Ilyas I, 2010: 45). Menurut abdul Azis (2014: 51) guru memiliki kemampuan dalam menyusun rencana pembelajaran serta kemampuan dalam melaksanakan interaksi atau kegiatan pembelajaran.

Peraturan Pemerintah (PP) Republik Indonesia Nomor 74 Tahun 2008 mengatur tentang Guru bahwa salah satu kompetensi yang harus dimiliki oleh seorang guru adalah kompetensi pedagogik, yakni kemampuan guru dalam mengelola pembelajaran yang didalamnya antara lain perencanaan pembelajaran, pelaksanaan pembelajaran yang mendidik dan dialogis, dan evaluasi hasil belajar. Perencanaan, pelaksanaan dan evaluasi merupakan kompetensi yang perlu dimiliki oleh guru. Dengan perencanaan yang baik diharapkan kegiatan pembelajaran dapat berlangsung sesuai dengan perencanaan yang sudah disiapkan. Evaluasi dilakukan sesuai dengan aspek-aspek yang akan diukur.

Standar Kompetensi merupakan suatu ukuran yang ditentukan dan dipersyaratkan untuk dimiliki seorang guru. Suparlan (2006:87) menyatakan standar kompetensi tersebut terdiri atas tiga komponen yaitu: pengelolaan pembelajaran, pengembangan profesi dan penguasaan akademik. Komponen pengelolaan pembelajaran terdiri atas penyusunan rencana pembelajaran, pelaksanaan interaksi belajar mengajar, penilaian prestasi belajar peserta didik, pelaksanaan tindak lanjut hasil penilaian prestasi belajar peserta didik. Komponen pengembangan profesi terdiri dari pengembangan profesi. Komponen penguasaan akademik terdiri dari pemahaman wawasan kependidikan, dan penguasaan bahan kajian akademik. Salah satu komponen yang harus dimiliki oleh seorang guru adalah kompetensi dalam mengelola pembelajaran. Berhasil tidaknya suatu pembelajaran tergantung dari bagaimana guru tersebut mampu mengelola pembelajaran di kelas.

Menurut Permendiknas nomor 16 tahun 2007 ada 4 kompetensi yang harus dimiliki seorang guru meliputi: 1) Kompetensi pedagogik, 2) kompetensi kepribadian, 3) kompetensi sosial, 4) kompetensi professional. Kompetensi Pedagogik meliputi pemahaman terhadap peserta didik, perancangan dan pelaksanaan pembelajaran, evaluasi hasil belajar, dan pengembangan peserta didik untuk mengaktualisasikan berbagai potensi yang dimiliki. Kompetensi kepribadian merupakan kemampuan personal yang mencerminkan kepribadian yang mantap, stabil, dewasa, arif, dan berwibawa, menjadi teladan bagi peserta didik, dan berakhlak mulia. Kompetensi sosial merupakan kemampuan guru untuk 
berkomunikasi dan bergaul secara efektif dengan peserta didik, sesame pendidik, tenaga kependidikan, orangtua/wali peserta didik, dan masyarakat sekitar. Kompetensi professional merupakan penguasaan materi pembelajaran secara luas dan mendalam yang mencakup penguasaan materi kurikulum mata pelajaran di sekolah dan substansi keilmuan yang menaungi materinya, serta penguasaan terhadap struktur dan metodologi keilmuannya.

Peneliti melakukan penelitian tentang analisis hambatan-hambatan yang dilakukan guru Sekolah Dasar di daerah Kabupaten Biak Numfor, Papua. Penelitian ini dimaksudkan untuk menjawab permasalahan: (1) faktorfaktor apa sajakah yang menjadi pengaruh dalam mempersiapkan kegiatan pembelajaran?, (2) faktor-faktor apa sajakah yang menjadi pengaruh dalam melaksanakan kegiatan pembelajaran?, (3) faktor-faktor apa sajakah yang menjadi pengaruh dalam melaksanakan evaluasi pembelajaran?, (4) Bagaimana usahausaha yang dilakukan guru-guru dalam mengatasi kesulitasi hambatan tersebut?

Penelitian yang dilakukan Syamsul Bahri (2011) menjelaskan bahwa guru tidak membuat rencana pembelajaran, kurangnya kepedulian dalam menganalisis hasil evaluasi, dan terbatasnya informasi yang diperoleh terkait pengayaan ilmu yang dimiliki, sarana dan prasarana yang kurang mendukung dalam melaksanakan pembelajaran.

Sedangkan Titik Rosilawati (2014: 61) menjelaskan bahwa rendahnya kinerja guru dalam pempersiapkan pembelajaran dipengaruhi oleh kualitas komitmen dan kompetensi yang dimiliki guru tersebut. Penelitian tersebut sejalan dengan penelitian yang dilakukan Heri Retnawati (2015) bahwa 4 kompetensi yang diukur dalam pembelajaran yaitu: penilaian kompetensi penilaian sikap spiritual, penilaian sikap sosial, penilaian pengetahuan dan penilaian keterampilan.

Penelitian yang membahas tentang faktor-faktor yang mempengauhi pembelajaran, penelitian yang Titik Rosilawati $(2014 ; 58)$ bahwa guru belum meiliki kecakapan atau keterampilan menyusun perangkat persiapan untuk pembelajaran, guru enggan untuk membuat perangkat pembelajaran.

Adapun peran dan fungsi guru dalam meningkatkan mutu pendidikan menurut Usman (2004:6-9) meliputi: 1) Guru sebagai demonstrator berfungsi untuk mendemonstrasikan suatu materi pembelajaran, sehingga lebih mudah dimengerti dan dipahami oleh siswa. Oleh karena itu guru harus mampu menguasai bahan atau materi pelajaran yang akan diajarkannya serta senantiasa mengembangkan kemampuannya yang pada akhirnya mampu memperagakan apa yang diajarkannya secara didaktis. 2) Guru sebagai pengelola kelas berfungsi untuk mengendalikan dan mengorganisasikan siswa di dalam kelas agar lebih terarah kepada tujuan pembelajaran. Oleh karena itu guru harus mampu mengelola kelas karena kelas merupakan lingkungan belajar serta merupakan suatu aspek dari lingkungan sekolah yang perlu diorganisasikan. 3) Guru sebagai mediator dan fasilitator berfungsi untuk memperagakan suatu media atau alat pembelajaran yang mendukung materi sehingga siswa lebih merasa jelas. Oleh karena itu guru hendaknya memiliki pengetahuan dan pemahaman yang cukup tentang media pendidikan sebagai alat komunikasi guna mengefektifkan pembelajaran. 4) Guru sebagai evaluator berfungsi untuk mengevaluasi hasil belajar siswa. Oleh karena itu guru harus melaksanakan evaluasi pada waktu-waktu tertentu selama satu periode pendidikan untuk mengadakan penilaian terhadap hasil yang telah dicapai, baik oleh pihak terdidik maupun oleh pendidik.

Kompetensi guru mengambarkan kompetensi yang dituntut dari seseorang yang memangku jabatan profesi guru. Artinya kompetensi yang ditampilkan itu menjadi ciri profesionalismenya, walaupun tidak semua kompetensi yang dimiliki seseorang menunjukkan bahwa apa dan bagaimana melakukan pekerjaan semata-mata, tetapi juga 
menguasai mengapa hal itu dilakukan berdasarkan konsep dan teori tertentu (Pranowo Narjosoeripto, 2012: 113).

Guru harus memiliki 4 kompetensi sebagai guru yang professional tetapi pada kenyataannya di Indonesia masih banyak guruguru yang professional. Banyak guru-guru di Indonesia yang belum memiliki 4 kompetensi sebagi seorang guru, hal tersebut juga dialami oleh guru-guru Sekolah Dasar di Kabupaten Biak Numfor, Papua. Salah satu kompetensi yang masih kurang dimiliki guru adalah kompetensi pedagogik.

Hasil diskusi dengan guru-guru Sekolah Dasar di Kabupaten Biak Numfor, Papua menunjukkan bahwa masih banyak guru-guru yang mengalami kesulitan dalam pengembangan kompetensi pedagogik. Kompetensi pedagogik terkait dengan perencanaan, pelaksanaan dan evaluasi pembelajaran. Guru mengalami kesulitan bagaimana merencanakan suatu pembelajaran yang baik dengan menggunakan model-model pembelajaran yang inovatif. Pada saat pelaksanaan pembelajaran, guru kesulitan menentukan media, sember belajar yang mampu menumbuhkan kreativitas siswa. Selain itu, evaluasi yang dilakukan guru hanya mengukur ranah kognitif saja dan biasanya dilakukan hanya di akhir semester. Hanya sedikit guru yang mengevaluasi siswa dari ranah psikomotorik dan afektif. Oleh karena itu peneliti menganalisis faktor-faktor apa sajakah yang mempengaruhi guru dalam pelaksanaan pembelajaran khususnya di daerah Kabupaten Biak Numfor, Papua.

Hambatan-hambatan ini juga relevan dengan penelitian yang dilakukan Heri Retnawati (2015) yang menyatakan bahwa guru mengalami hambatan dalam mengatur waktu pada perencanaan pembelajaran, merencanakan pembelajaran, merencanakan penilaian sikap, penilaian keterampialan, penilaian pengetahuan, serta guru mengalami hambatan dalam pembuatan RPP. Hal ini juga sejalan dengan penelitian Akhmad Wahyuddin (2009) yang menyebutkan bahwa guru masih mengalami hambatan dalam menyusun Rencana Pelaksanaan Pembelajaran, guru juga masih mengalami kesulitan dalam menyusun penilaian.

Penelitian yang dilakukan Hilda S.M dan Supramono (2015) menyebutkan bahwa guru belum fokus pada siswa secara individu, guru masih kurang pengetahuan akan manajemen kelas.

\section{METODE PENELITIAN}

Jenis penelitian ini adalah penelitian deskriptif. Penelitian ini dilaksanakan di bulan Oktober 2016 dan dilaksanakan di Universitas Kristen Satya Wacana Salatiga. Subjek penelitian ini adalah guru-guru Sekolah Dasar di Kabupaten Biak Numfor yang berjumlah 31 orang dengan jumlah 18 orang guru laki-laki dan 13 orang guru perempuan. Jenis penelitian yang digunakan dalam penelitian ini adalah penelitian diskriptif, karena hanya menjelaskan keadaan sesungguhnya dari objek yang diteliti. Teknik pengumpulan data dengan menggunakan non tes yang berupa angket dan wawancara. Sebelum disebarkan kepada responden, angket terlebih dahulu divalidasi. Pada penelitian ini, angket sudah divalidasi sebelumnya.

Hasil validasi menunjukkan bahwa angket valid dan reliabel. Hasil validasi instrument berupa angket terdiri dari 15 (lima belas) pernyataan yang diujikan, ada 14 (empat) pernyataan yang valid dan yang tidak valid ada 1 (satu) penyataan. Dengan demikian instrumen yang berupa angket tersebut dapat digunakan sebagai

Hasil uji reliabilitas instrumen berupa angket yang digunakan diketahui bahwa reliabilitasnya 0,805 sehingga masuk dalam kriteria reliabilitas bagus dan diterima untuk digunakan.

Teknik analisis yang digunakan dalam penelitian ini adalah mencari frekuensi dan presentase dari hasil angket, kemudian hasil presentase angket digunakan untuk mendeskripsikan hambatan-hambatan yang dialami 
Analisa Faktor-Faktor yang Mempengaruhi Proses Belajar Guru-Guru Sekolah Dasar | Indri Anugraheni

guru-guru SD di Kabupaten Biak Numfor serta usaha-usaha yang dilakukan guru-guru dalam mengatasi hambatan-hambatan tersebut. Peneliti membagi menjadi 3 indikator yaitu: persiapan guru sebelum melaksanakan pembelajaran, perencanaan guru dalam menggunakan metode dan media, penilaian yang dilakukan guru. Masing-masing aspek akan diukur dengan berpedoman pada indikator. Persiapan guru sebalum melaksanakan pembelajaran, terdiri dari aspek: Persiapan sebelum pembelajaran, hambatan dalam melakukan persiapan, membuat RRP, hambatan membuat RPP, mengembangkan bahan Ajar. Perencanaan guru dalam menggunakan metode dan media terdiri dari aspek: Merencanakan metode yang digunakan, ambatan dalam pemilihan metode, menggunakan media dalam kegiatan pembelajaran, hambatan dalam pemilihan media. Penilaian yang dilakukan guru terdiri dari: Melakukan penilaian dan hambatan dalam melakukan penilaian (penilaian proses dan akhir).

\section{HASIL PENELITIAN DAN PEMBAHASAN}

Hasil penelitian menunjukkan bahwa guru mengalami hambatan dalam pelaksanaan pembelajaran matematika. Berikut ini adalah tabel hasil analisis angket:

Tabel 1. Analisis Persiapan guru sebelum melaksanakan pembelajaran

\begin{tabular}{lcccc}
\hline \multirow{2}{*}{ Aspek yang diukur } & \multicolumn{2}{c}{ Frekuensi } & \multicolumn{2}{c}{ Presentase } \\
\cline { 2 - 5 } & Y & T & Y & T \\
\hline Persiapan sebelum pembelajaran & 30 & 1 & 96,80 & 3,20 \\
Hambatan dalam melakukan persiapan & 15 & 16 & 48,40 & 51,60 \\
Membuat RRP & 28 & 3 & 90,30 & 9,70 \\
Hambatan membuat RPP & 23 & 8 & 74,20 & 25,80 \\
Mengembangkan bahan Ajar & 26 & 5 & 83,90 & 16,10 \\
Hambatan mengembangkan Bahan Ajar & 25 & 6 & 80,60 & 19,40 \\
\hline
\end{tabular}

Berdasarkan analisis tabel 1 diatas menunukkan bahwa 96,80\% guru di SD di Kabupaten Biak Numfor melakukan persiapan sebelum pembelajaran dan 3,20\% guru tidak melakukan persiapan. selain itu, $48,40 \%$ guru mengalami hambatan dalam mempersiapan pembelajaran, sedangkan $51,60 \%$ guru tidak mengalami hambatan. Hambatan-hambatan tersebut dikarenakaa 1) kurangnya buku penunjang bagi guru, 2) kurangnya buku siswa, 3) karena kurangnya tenaga pendidik sehingga guru harus merangkap sebagai kepala sekolah, guru harus mengajar lebih dari satu kelas secara bersamaan, 4) Jarak yang jauh antara sekolah dengan tempat tinggal sehingga guru tidak sempat untuk mempersiapkan pembelajaran.

Berdasarkan kenyataan tabel 1 baris ketiga kolom kelima menunjukkan bahwa 90,30 guru membuat RPP dan hanya 9,70 persen yang tidak membuat RPP. 74,20\% guru mengalami hambatan dalam membuat RPP dan $25,80 \%$ tidak mengalami hambatan. Hambatanhambatan yang dialami guru-guru SD di Kabupaten Biak Numfor karena faktor 1) kurikulum yang berubah-ubah (pemahaman kurikulum ktsp belum kuat sudah ditambah dengan kurikulum 2013), 2) kurangnya sosialisasi kurikulum 2013 (pembuatan RPP).

Dari tabel 1 tampak bahwa 83,90\% guru mengembangkan bahan ajar dan $16,10 \%$ tidak mengembangkan bahan ajar. $80,60 \%$ menngalami kesulitan dalam mengembangkan bahan ajar dan $19,40 \%$ tidak mengalami hambatan dalam mengembangkan bahan ajar. Hambatan-hambatan ini dikarenakan 1) guru masih kurang menguasai materi yang akan diajarkan, 2) terbatasnya buku pegangan guru dan buku siswa. 
Kelola: Jurnal Manajemen Pendidikan, Vol. 4, No. 2, Juli-Desember 2017

Hambatan ini juga sejalan dengan penelitian yang dilakukan oleh Surahman (2015) yang menyatakan bahwa fasilitas

penunjang dalam penyususnan RPP dan penunjang proses pembelajaran yang sangat kurang.

Tabel 2. Analisis Perencanaan guru dalam menggunakan metode dan media

\begin{tabular}{lcccc}
\hline \multirow{2}{*}{ Aspek yang diukur } & \multicolumn{2}{c}{ Frekuensi } & \multicolumn{2}{c}{ Presentase } \\
\cline { 2 - 5 } & Y & T & Y & T \\
\hline Merencanakan metode yang digunakan & 29 & 2 & 93,50 & 6,50 \\
Hambatan dalam pemilihan metode & 24 & 7 & 77,40 & 22,60 \\
Menggunakan media dalam kegiatan pembelajaran & 23 & 8 & 74,20 & 25,80 \\
Hambatan dalam pemilihan media & 30 & 1 & 96,80 & 3,20 \\
\hline
\end{tabular}

Berdasarkan kenyataan yang tampak dari tabel 2 bahwa 93,50\% guru merencanakan metode dalam pembelajaran dan $6,50 \%$ tidak merencanakan metode yang akan digunakan dalam pembelajaran. $77,40 \%$ guru mengalami hambatan dalam menentukan metode yang digunakan pada saat pembelajaran dan $22,60 \%$ guru tidak mengalami hambatan. Hambatanhambatan tersebut terdiri dari 1) kurangnya pengetahuan tentang motode-metode, modelmodel, serta trategi-strategi dalam pembelajaran,; 2) matri yang ada dibahan ajar tidak sesuai dengan kondisi di lapangan (contohnya: materi tentang candi Borobudur tidak sesuai dengan kondisi di Biak karena di Biak tidak ada candi; materi tentang transportasi seperti becak, di Papua tidak ada becak sehingga anak kesulitan untuk membayangkan alat transportasi becak),

Berdasarkan tabel 2 menunjukkan bahwa $74,20 \%$ guru SD di Kabupaten Biak Numfor menggunakan media dalam pembelajaran dan $25,80 \%$ tidak menggunakan media dalam pembelajaran. $96,80 \%$ mengalami hambatan dalam memilih media yang tepat dengan pembelajaran dan 3,20\% guru tidak mengalami hambatan. Hambatan yang dialami guru adalah 1) kurangnya refrensi (sumber-sumber) media pembelajaran serta buku pembelajaran yang sesuai dengan materi yang akan diajarkan, 2) terbatarnya pengetahuan tentang media pembelajaran yang sesuai dengan materi yang diajarkan, 3) terbatasnya dana bagi pembuatan media. Media pembelajaran, buku-buku pembelajaran merupakan fasilitas yang harus dimiliki siswa tetapi pada kenyataannya masih banyak fasilitas yang belum dimiliki. Hal ini sejalan dengan penelitian yang dilakukan oleh Rini Kristiantari (2014) menyebutkan bahwa sekolah masih kesulitan dalam penyediaan fasilitas pembelajaran.

Tabel 3. Analisis Penilaian yang dilakukan guru

\begin{tabular}{lcccc}
\hline \multirow{2}{*}{ Aspek yang diukur } & \multicolumn{2}{c}{ Frekuensi } & \multicolumn{2}{c}{ Presentase } \\
\cline { 2 - 5 } & Y & T & Y & T \\
\hline Melakukan penilaian & 31 & 0 & 100,00 & 0,00 \\
$\begin{array}{l}\text { Hambatan dalam melakukan penilaian } \\
\text { (penilaian proses dan akhir) }\end{array}$ & 28 & 3 & 90,30 & 9,70 \\
\hline
\end{tabular}

Dari analisis tabel 3 menyatakan bahwa semua guru-guru SD di Kabupaten Biak Numfor melakukan penilaian. 90,30\% mengalami kesulitan dalam melakukan penilaian baik penilaian proses maupun penilaian produk. Hal ini dikarenakan kurangnya pengetahun tentang penilaian psikomotorik, penilaian afektif sehingga guru hanya melakukan penilaian kognitif di akhir pembelajaran, jarak sekolah dengan tempat 
Analisa Faktor-Faktor yang Mempengaruhi Proses Belajar Guru-Guru Sekolah Dasar | Indri Anugraheni

tinggal yang jauh sehingga guru tidak sempat melakukan penilaian proses.

Hal ini sejalan dengan penelitian yang dilakukan Syamsul Bahri di daerah dataran Tinggimoncong menyebutkan bahwa faktor yang mempengaruhi guru dalam pembelajaran adalah guru tidak membuat rencana pembelajaran, kurangnya kepedulian dalam menganalisis hasil evaluasi belajar, terbatasnya informasi yang diperoleh serta sarana dan prasarana yang tidak memadai dalam melaksanakan pembelajaran.

\section{SIMPULAN DAN SARAN Simpulan}

Dari hasil angket yang dibagikan kepada 31 guru-guru SD di Kabupaten Biak Numfor menunjukan bahwa banyak hambatanhambatan yang dialami guru. Hambatanhambatan yang dialami guru SD di Kabupaten Biak Numfor yaitu: 1) analisis persiapan guru sebelum melaksanakan pembelajaran, 2) analisis perencanaan guru dalam menggunakan metode dan media, 3) analisis penilaian yang dilakukan guru.

Hambatan-hambatan yang dialami guru dalam mempersiapkan pembelajaran adalah: 1) kurangnya buku penunjang bagi guru, 2) kurangnya buku siswa, 3) karena kurangnya tenaga pendidik sehingga guru harus merangkap sebagai kepala sekolah, guru harus mengajar lebih dari satu kelas secara bersamaan, 4) Jarak yang jauh antara sekolah dengan tempat tinggal sehingga guru tidak sempat untuk mempersiapkan pembelajaran. Hambatan-hambatan yang dialami guru-guru SD di Kabupaten Biak Numfor karena faktor 1) kurikulum yang berubah-ubah (pemahaman kurikulum KTSP belum kuat sudah ditambah dengan kurikulum 2013), 2) kurangnya sosialisasi kurikulum 2013 (pembuatan RPP).

Hambatan-hambatan yang dialami guru dalam merencanakan dan menggunakan metode serta media yang sesuai dengan pembelajaran yaitu: 1) kurangnya pengetahuan tentang motode-metode, model-model, serta trategi-strategi dalam pembelajaran, 2) matri yang ada dibahan ajar tidak sesuai dengan kondisi di lapangan (contohnya: materi tentang candi Borobudur tidak sesuai dengan kondisi di Biak karena di Biak tidak ada candi; materi tentang transportasi seperti becak, di Papua tidak ada becak sehingga anak kesulitan untuk membayangkan alat transportasi becak). Hambatan yang dialami guru adalah 1) kurangnya refrensi (sumber-sumber) media pembelajaran yang sesuai dengan materi yang akan diajarkan, 2) terbatarnya pengetahuan tentang media pembelajaran yang sesuai dengan materi yang diajarkan, 3) terbatasnya dana bagi pembuatan media.

Hambatan-hambatan yang dialami guru dalam melakukan kegiatan evaluasi pembelajaran adalah: 1) kurangnya pengetahuan tentang penilaian psikomotorik, penilaian afektif sehingga guru hanya melakukan penilaian kognitif di akhir pembelajaran. 2) jarak sekolah dengan tempat tinggal yang jauh sehingga guru tidak sempat melakukan penilaian proses.

Usaha-usaha yang dilakukan guru dalam mengatasi hambatan tersebut adalah1) banyak siswa yang tidak mempunyai buku pegangan maka guru menatat materi di papan tulis, 2) guru menyiapkan pembelajaran sesuai dengan kemampuan guru, 3) guru menggunakan media yang ada di sekolah.

\section{Saran}

Saran bagi pemerintah daerah Kabupaten Biak Numfor adalah perlunya a) pelatihanpelatihan terkait pembengangan kompetensi bagi guru-guru di Kabupaten Biak Numfor, Papua; b) Seminar terkait model-model pembelajaran, media pembelajaran, evaluasi pembelajaran (ranah kognitif, afektif dan psikomotorik) bagi guru-guru di Kabupaten Biak Numfor, Papua. Saran bagi FKIP UKSW Salatiga adalah menjalin kerjasama dan mengadakan program-program atau kegiatankegiatan yang mampu meningkatkan kompetensi guru untuk menjadi guru yang 
Kelola: Jurnal Manajemen Pendidikan, Vol. 4, No. 2, Juli-Desember 2017

professional. Saran bagi Guru (pendidik) adalah mengikuti pelatihan-pelatihan, seminar yang diadakan oelh Dinas Pendidikan; mengembangkan diri dengan membaca bukubuku refrensi.

\section{DAFTAR PUSTAKA}

Abdul Azis. 2014. Kompetensi Guru dalam penggunaan media Mutu Pembelajaran. Jurnal Pelopor Pendidikan, Vol 5 no 1. (49-57).

Akhmad Wahyuddin Rauf. (2009). Deskripsi Tentang Hambatan Guru Dalam Implementasi Kurikulum Tingkat Satuan Pendidikan (KTSP) Di SMU Negeri 4 Watampone. Jurnal Medtek, 1(1).

Heri Retnawati. (2015). Hambatan Guru Metamtika Sekolah Menengah Pertama Dalam Menerapkan Kurikulum Baru. Jurnal Cakrawala Pendidikan, Th XXXIV (3), 390 - 403.

Hilda Saranita M dan Supramono. (2015). Analisis Akar Masalah Ketidakefektifan Manajemen Kelas di Sekolah Dasar di Salatiga dan Sekitarnya. Jurnal Kelola (Jurnal Manajemen Pendidikan), 2(2), $221-235$.

Mg. Rini Kristiantari. (2014). Analisis Kesiapan Guru Sekolah Dasar Dalam Mengimplementasikan Pembelajara Tematik Integratif Menyongsing Kurikulum 2013. Jurnal Pendidikan Indonesia, 3(2), $460-470$.

Muh. Ilyas Ismail. (2010). "Kinerja dan Kompetensi Guru dalam Pembelajaran”. Jurnal Lentera Pendidikan, Vol 13 (No 1), $44-63$.

Peraturan Menteri Pendidikan Nasional Republik Indonesia No. 16 Tahun 2007 tentang Standar Kualifikasi Akademik dan Kompetensi Guru.

Pranowo Narjosoeripto. (2012). Profesionalisme Guru dan Perspektif Global. Procceding Seminar Nasional "Profesionalisme Guru dalam Perspektif Global". Univet Bantara Sukoharjo, $112-119$.

Suparlan. (2006). Guru Sebagai Profesi. Yogyakarta: Hikayat Publishing.
Surahman Nur. (2015). Studi tenang Faktor Pengaruh Guru Biologi dalam menyusun Rancangan Pelaksanaan Pembelajaran Kurikulum Tingkat Satuan Pendidikan di SMP Sek Kecamatan Bastem Kabupaten Luwu. Jurnal Bionature, 2 (Oktober 2015), $110-116$.

Syamsul Bahri. (2011). Faktor yang mempengaruhi Kinerja Guru SD di Dataran Tinggimonco Gowa. Jurnal Medtek, Vol 3, No 2 (Oktober 2011).

Titik Rosilawati. (2014). Supervisi Akademik dalam Upaya Peningkatan Motivasi Guru Menyusun Perangkat Persiapan Pembelajaran. Jurnal Penelitian Pendidikan Tindakan Sekolah, Vol 1 (No 2), $57-62$.

Usman. 2004. Menjadi Guru Profesional. Bandung: Angkasa.

Undang-undang Republik Indonesia, Nomor 14 tahun 2005. Tentang guru dan dosen. 